\title{
Pengaruh Corporate Governance Terhadap Luas Pengungkapan Integrated Reporting dan Implikasinya terhadap Nilai Perusahaan
}

\author{
Lucky Mandalika1 \\ Fakultas Ekonomi dan Bisnis \\ Universitas Mataram, Indonesia \\ Email: luckymandalika94@gmail.com
}

\author{
Hermanto $^{2}$ \\ Fakultas Ekonomi dan Bisnis \\ Universitas Mataram, Indonesia
}

\author{
Lilik Handajani ${ }^{3}$ \\ Fakultas Ekonomi dan Bisnis \\ Universitas Mataram, Indonesia
}

\begin{abstract}
ABSTRAK
Penelitian ini bertujuan menganalisis pengaruh corporate governance terhadap luas pengungkapan integrated reporting (IR) dan implikasinya terhadap nilai perusahaan pada perusahaan publik periode 2017-2018. Corporate governance diproksikan dengan proporsi komisaris independen, keahlian dan frekuensi pertemuan komite audit, kepemilikan institusional dan asing. Hasil penelitian menunjukkan terdapat pengaruh positif signifikan frekuensi pertemuan komite audit pada luas pengungkapan IR. Sementara itu, tidak terdapat pengaruh proporsi komisaris independen, keahlian komite audit, kepemilikan institusional dan asing pada luas pengungkapan IR. Temuan lain juga menunjukkan tidak terdapat pengaruh luas pengungkapan IR pada nilai perusahaan. Bagi manajer, penelitian ini menyiratkan pengungkapan IR untuk meningkatkan kinerja perusahaan. Bagi investor, IR diharapkan dapat membantu dalam mengambil keputusan investasi.
\end{abstract}

Kata Kunci: Integrated Reporting; Corporate Governance; Nilai Perusahaan.

\section{The Effect of Corporate Governance on Integrated Reporting Disclosure and Implication on Corporate Value}

\section{ABSTRACT}

The objective of this study is to analyze the effect of corporate governance on the extent of integrated reporting (IR) disclosure and its implications for corporate value in public companies for the 2017-2018 period. Corporate governance is proxied by the proportion of independent commissioners, audit committee expertise, frequency of audit committee meetings, institutional ownership, and foreign ownership. The results showed a significant positive effect on the frequency of audit committee meetings on IR disclosure area. Meanwhile, there is no influence of the proportion of independent commissioners, audit committee expertise, institutional and foreign ownership on the extent of IR disclosure. Other findings also reveal that there is no influence of IR disclosure on corporate value. For managers, this research implies IR disclosure to improve company performance. For investors, IR are expected to help in making investment decisions.

Keywords: $\quad$ Integrated Reporting; Corporate Governance; Corporate Value.

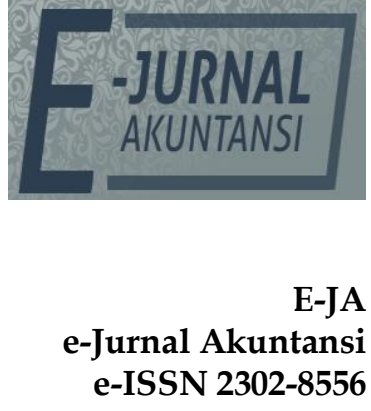

Vol. 30 No. 3

Denpasar, Maret 2020

Hal. 556-570

Artikel Masuk:

29 November 2019

Tanggal Diterima: 4 Februari 2020 


\section{PENDAHULUAN}

Pelaporan perusahaan secara tradisional hanya memuat informasi keuangan dianggap tidak cukup untuk memenuhi kebutuhan informasi dari berbagai stakeholders (Adams \& Simnett, 2011). Oleh karena itu, perusahaan meningkatkan pelaporan informasi keuangan dan nonkeuangan untuk memenuhi kebutuhan informasi bagi investor, pemegang saham, dan stakeholders (Cohen et al., 2012). Seiring dengan meningkatnya kebutuhan pelaporan dan sebagai antisipasi dari tuntutan regulasi, perusahaan berusaha mengembangkan sistem pelaporan keuangan yang memiliki keunggulan bersaing (PwC, 2012). Untuk itu, International Integrated Reporting Council (IIRC) mengembangkan pendekatan baru dalam pelaporan, yaitu Integrated Reporting (IR).

IIRC mendefinisikan IR sebagai suatu komunikasi ringkas mengenai strategi, tata kelola, kinerja, dan prospek perusahaan dalam konteks lingkungan eksternal perusahaan yang mengarah pada penciptaan nilai jangka pendek, jangka menengah, dan jangka panjang. Menurut Busco et al. (2013), IR adalah proses yang menghasilkan komunikasi melalui penciptaan nilai dari waktu ke waktu. IR berupaya menyelaraskan informasi yang relevan mengenai strategi, sistem tata kelola, kinerja, dan prospek organisasi di masa depan dengan mencerminkan ekonomi, lingkungan, dan sosial tempat perusahaan beroperasi (PwC, 2012). IR mencakup depalan elemen, yaitu (1) Organizational overview and external environmental, (2) Governance, (3) Business model, (4) Risk and opportunity, (5) Strategy and resource allocation, (6) Performance, (7) Outlook, dan (8) Basic of preparation and presentation (IIRC, 2013).

IR dapat meningkatkan transparansi dalam perusahaan, sehingga dapat meningkatkan kepercayaan stakeholder (Azam et al., 2011; Serafeim, 2015; Cheng et al., 2014) dalam (Utami, 2016). Transparansi dan pengungkapan dalam annual report (AR) perusahaan merupakan salah satu pilar dari corporate governance (CG) (Nindiasari, 2018). Di Indonesia, telah terjadi skandal yang diakibatkan karena kurangnya pengungkapan yang dilakukan oleh perusahaan. Telah terjadi perseteruan antara pemegang saham mayoritas dengan pemegang saham minoritas PT Sumalindo Lestari Jaya yang bermula dari kecurigaan pemegang saham minoritas atas keuntungan yang diterima. Pada tahun 2012, PT Sumalindo memiliki lebih dari 840 hektar hutan alam dan 73 ribu hektar hutan tanaman industri. PT Sumalindo bahkan termasuk ke dalam lima besar produsen kayu di dunia dan menguasi lebih dari 30\% pasar di Indonesia. Namun, selama lima tahun belakangan, PT Sumalindo tidak pernah membukukan laba. Terlebih lagi, harga saham pada tahun 2007 sebesar Rp 4.800 pada tahun 2012 turun drastis pada kisaran Rp 100. Oleh karena itu, Deddy Hartawan Jamin, mewakili pemegang saham minoritas mengajukan permohonan pengecekan pembukuan rugi-laba perusahaan dalam RUPS, namun permohonan Deddy kalah dalam voting. Karena tidak menerima respon positif dalam RUPS, akhirnya Deddy mengajukan gugatan ke Pengadilan Negeri Jakarta Selatan (RMOL, 2012).

Kasus yang terjadi pada PT Sumalindo Lestari Jaya mencerminkan ketidaktransparanan perusahaan dalam pengungkapan informasi kepada pemegang saham, terutama pemegang saham minoritas. Akibat dari perusahaan yang tidak transparan, tercipta kesenjangan antara pihak yang memiliki akses informasi kuat dengan pihak yang memiliki akses informasi lemah (Nindiasari, 
2018). Dengan demikian, dapat diketahui bahwa telah terjadi konflik kepentingan antara pemegang saham mayoritas dengan pemegang saham minoritas dalam perusahaan.

Agency conflict yang terjadi antara agent dan principal maupun antara pemegang saham mayoritas dengan minoritas dapat diminimalisir dengan pengimplementasian $C G$ sebagai sarana untuk mengawasi manajemen. Mekanisme CG, yaitu komisaris independen, komite audit, dan struktur kepemilikan memiliki peranan penting untuk mencapai transparansi dalam perusahaan (Wulandari \& Kiswanto, 2016). Komisaris independen dalam tata kelola perusahaan dapat memberikan tekanan kepada perusahaan untuk mengungkapkan IR yang lebih luas untuk mewujudkan transparansi dan responsibilitas. Semakin besar proporsi komisaris independen dalam struktur dewan, diharapkan dapat mendorong untuk mengungkapkan pelaporan perusahaan, termasuk IR (Ahmad, 2017). Anggota komite audit yang memiliki keahlian di bidang akuntansi dan keuangan diyakini dapat meningkatkan kualitas pelaporan keuangan (Abernathy et al., 2013). Jadi, dapat disimpulkan bahwa anggota komite audit yang memiliki keahlian akuntansi dan keuangan dapat meningkatkan luas pengungkapan IR. Selain itu, anggota komite audit juga harus melakukan pertemuan rutin agar kegiatan pengawasan menjadi semakin efektif dan efisien. Chariri \& Januarti (2017) menyatakan bahwa komite audit dengan keahlian akuntansi dan/atau keuangan serta rutin melaksanakan pertemuan memiliki pengaruh positif terhadap luas lingkup elemen IR. Kepemilikan institusional dalam suatu perusahaan diharapkan dapat dijadikan sebagai tindakan pengawasan untuk membatasi perilaku penyelewengan oleh manajer dan juga agar manajer lebih efektif dalam pengambilan keputusan (Wulandari \& Budiartha, 2014). Kepemilikan asing juga memiliki peranan dalam pengungkapan informasi terkait aktivitas perusahaan.

Konflik kepentingan antara manajer dan pemegang saham juga dapat terjadi ketika perusahaan berupaya untuk meningkatkan nilai perusahaan. Untuk mengurangi adanya konflik tersebut, perusahaan harus menerapkan CG. Selain itu, perusahaan juga dapat mengimplementasikan IR. Dengan demikian, diharapkan dapat memberikan nilai tambah bagi investor. Terdapat beberapa penelitian mengenai hubungan antara IR dengan nilai perusahaan, yang dilakukan oleh Churet \& Eccles (2014) dan Suttipun (2017). Churet \& Eccles (2014) menunjukkan bahwa tidak terdapat hubungan yang signifikan antara IR dengan kinerja keuangan perusahaan. Namun, Suttipun (2017) menunjukkan bahwa pelaporan manufactured capital berpengaruh positif terhadap nilai perusahaan, sedangkan untuk pelaporan environmental capital berpengaruh negatif terhadap nilai perusahaan.

Secara empiris, penelitian mengenai pengaruh CG terhadap tingkat pengungkapan sukarela telah dilakukan oleh peneliti-peneliti sebelumnya yang menunjukkan hasil yang beragam, diantaranya adalah Akhtaruddin \& Haron (2010), Rouf (2011), dan Haji (2015). Penelitian dari Akhtaruddin \& Haron (2010) menunjukkan bahwa independensi dan keahlian komite audit berpengaruh positif signifikan terhadap pengungkapan sukarela. Kemudian, Rouf (2011) menunjukkan komite audit dan struktur kepemimpinan dewan berpengaruh positif signifikan terhadap tingkat pengungkapan sukarela. Selanjutnya, Haji 
(2015), menunjukkan bahwa komite audit berpengaruh positif signifikan terhadap intellectual capital disclosure.

Penelitian ini termotivasi oleh IR yang merupakan konsep pelaporan baru yang menggabungkan antara pelaporan keuangan dan nonkeuangan. Selain itu, penelitian mengenai IR di negara berkembang yang memiliki tingkat sustainability, regulasi, dan pasar yang berbeda dengan negara maju masih sangat sedikit dilakukan, termasuk di Indonesia. Perbedaan hasil penelitian terdahulu (research gap) dari Akhtaruddin \& Haron (2010), Rouf (2011), dan Haji (2015) juga memotivasi peneliti untuk menguji kembali pengaruh CG terhadap luas pengungkapan sukarela yang diukur dengan menggunakan IR.

Dalam penelitian ini peneliti mengeksplorasi beberapa kebaruan, yaitu pengungkapan sukarela diukur dengan menggunakan IR. Penelitian terdahulu mengenai IR lebih banyak dilakukan di negara-negara maju, seperti Amerika Serikat, Australia, Selandia Baru, Afrika Selatan, dan negara-negara Eropa (Suttipun, 2017). Selanjutnya, peneliti menggunakan periode penelitian lebih dari satu tahun, yaitu periode 2017 dan 2018 pada seluruh perusahaan publik yang terdaftar di Bursa Efek Indonesia (BEI).

Berdasarkan latar belakang yang telah dipaparkan, rumusan masalah adalah sebagai berikut: 1. Apakah proporsi komisaris independen, keahlian komite, frekuensi pertemuan komite audit, kepemilikan institusional, dan kepemilikan asing berpengaruh terhadap luas pengungkapan IR? 2. Apakah luas pengungkapan IR berpengaruh terhadap nilai perusahaan?

Agency theory menjustifikasi bahwa komisaris independen dapat mengontrol perilaku oportunistik manajer, sehingga dapat membantu mengurangi agency problem dan menekan agency cost antara pemegang saham dan manajer. Semakin tinggi proporsi komisaris independen dalam perusahaan, maka semakin efektif dan efisien dalam mengawasi manajer sehingga manajer dapat bekerja sesuai dengan keinginan dari pemegang saham (Hermalin \& Weisbach, 1988). Jadi, semakin tinggi proporsi komisaris independen dalam perusahaan diharapkan mampu memotivasi perusahaan untuk mengungkapkan lebih banyak informasi dan meningkatkan pengungkapan pelaporan, termasuk pelaporan IR. Namun, Rouf (2011) menunjukkan bahwa dewan independen tidak berpengaruh terhadap luas pengungkapan sukarela. Ahmad (2017) juga menunjukkan bahwa proporsi komisaris independen tidak berpengaruh terhadap IR. Sementara itu, Frias-Aceituno et al. (2013) menyatakan sebaliknya, bahwa dewan direksi berpengaruh terhadap penyebaran integrated information.

$\mathrm{H}_{1}$ : Semakin tinggi proporsi komisaris independen, semakin luas pengungkapan IR.

Komite audit akan memiliki kinerja yang efektif jika memiliki keahlian khusus, terutama dalam bidang keuangan dan akuntansi, sehingga pengawasan yang dilakukan juga akan lebih efektif. Dengan demikian dapat mengurangi terjadinya asimetri informasi dan menyelaraskan perbedaan kepentingan antara principal dengan agent. Berdasarkan hasil penelitian oleh Akhtaruddin \& Haron (2010) bahwa keahlian komite audit berpengaruh positif signifikan terhadap pengungkapan sukarela. Kemudian Haji (2015) membuktikan bahwa terdapat peran positif signifikan dari keahlian komite audit terhadap pengungkapan intellectual capital. Hasil penelitian tersebut didukung oleh Chariri \& Januarti 
(2017) yang menyatakan bahwa keahlian komite audit di bidang keuangan dan/atau akuntansi berpengaruh positif terhadap luas lingkup IR. Hal tersebut menunjukkan bahwa semakin banyak anggota komite audit yang memiliki keahlian di bidang keuangan dan/atau akuntansi akan semakin banyak informasi mengenai IR yang disajikan dalam AR perusahaan. Namun, hasil penelitian yang dilakukan oleh Haji \& Anifowose (2016) menemukan bahwa tidak terdapat hubungan yang signifikan antara independensi dan keahlian keuangan komite audit terhadap praktik IR.

$\mathrm{H}_{2}$ : Semakin tinggi keahlian komite audit, semakin luas pengungkapan IR.

Agency theory menyatakan bahwa kualitas pengawasan yang baik dapat meminimalkan perilaku oportunistik manajer. Untuk menjalankan fungsi pengawasan atas pelaporan dan sistem pengendalian internal yang efektif, serta meningkatkan kualitas informasi perusahaan, komite audit harus melakukan pertemuan rutin (Lisic et al., 2015). Berdasarkan hasil penelitian oleh Haji (2015), pertemuan rutin komite audit berpengaruh positif signifikan terhadap pengungkapan intellectual capital. Kemudian hasil penelitian oleh Haji \& Anifowose (2016) menunjukkan bahwa pertemuan komite audit memiliki hubungan positif signifikan dengan tingkat dan kualitas praktik IR. Hasil penelitian tersebut didukung oleh penelitian Chariri \& Januarti (2017), frekuensi pertemuan komite audit mempengaruhi IR yang disajikan dalam AR perusahaan. Semakin sering komite audit menyelenggarakan pertemuan, maka semakin banyak informasi dalam IR yang akan disajikan oleh perusahaan.

$\mathrm{H}_{3}$ : Semakin tinggi frekuensi pertemuan komite audit, semakin luas pengungkapan IR.

Investor institusional memiliki kemampuan dalam mengendalikan pihak manajemen melalui proses pengawasan yang efektif sehingga dapat mengurangi tindakan oportunistik manajer. Institusi biasanya dapat menguasai mayoritas saham karena memiliki sumber daya yang besar dibandingkan dengan pemegang saham lainnya. Oleh karena itu, pihak institusional dapat memberikan pengawasan yang lebih ketat terhadap kebijakan manajemen perusahaan (Tamba, 2011). Dengan adanya kepemilikan institusional dalam suatu perusahaan diharapkan mampu menstimulasi perusahaan mengungkapkan item IR lebih banyak sehingga dapat digunakan oleh para stakeholder. Namun, berdasarkan hasil penelitian oleh Ahmad (2017), Indrawati et al. (2017), dan Novaridha (2017) menunjukkan bahwa kepemilikan institusional tidak berpengaruh terhadap IR.

$\mathrm{H}_{4}$ : Semakin tinggi kepemilikan institusional, semakin tinggi luas pengungkapan IR.

Kepemilikan asing merupakan kepemilikan saham perusahaan oleh foreign stakeholder. Foreign shareholder lebih mendukung perusahaan yang mengungkapkan lebih banyak informasi (Nurrahman \& Sudarno, 2013). Foreign shareholder memiliki permintaan pengungkapan informasi sosial, ekonomi, dan lingkungan lebih banyak, sehingga foreign stakeholder akan mendorong perusahaan melakukan pengungkapan yang lebih besar kepada para stakeholder, termasuk pengungkapan IR. Perusahaan yang sebagian besar sahamnya dimiliki oleh asing biasanya lebih sering mengalami asimetri informasi dikarenakan hambatan geografis dan Bahasa. Oleh sebab itu, untuk meminimilisirnya, 
perusahaan terdorong untuk mengungkapkan informasinya secara luas dan sukarela Xiao et al., 2004 dalam (Nurrahman \& Sudarno, 2013). Namun, Ahmad (2017) menunjukkan bahwa kepemilikan asing tidak berdampak terhadap IR.

$\mathrm{H}_{5}$ : Semakin tinggi kepemilikan asing, semakin luas pengungkapan IR.

Stakeholder theory menjustifikasi bahwa perusahaan akan melakukan kegiatan dan tindakan untuk memenuhi tuntutan dari para stakeholder. Konsep pengungkapan IR didukung oleh stakeholder theory karena perusahaan tidak hanya bergantung kepada pemegang saham saja, tetapi juga bergantung kepada stakeholder. Oleh karena itu, beberapa perusahaan besar telah memperkenalkan IR untuk memudahkan stakeholder dalam pengambilan keputusan (FriasAceituno et al., 2013; Serafeim, 2015). Peningkatan nilai perusahaan merupakan tujuan utama perusahaan. Dengan bertambahnya nilai perusahaan, juga akan menimbulkan sustainable development bagi perusahaan yang dapat diwujudkan jika perusahaan memperhatikan faktor keuangan dan nonkeuangan. Di dalam pengungkapan IR, perusahaan akan mengungkapkan mengenai informasi keuangan dan nonkeuangan perusahaan, termasuk mengenai strategi, tata kelola, kinerja, dan prospek perusahaan dalam jangka pendek, menengah, dan panjang. Dengan pengungkapan IR diharapkan perusahaan akan mendapatkan kepercayaan lebih dari para pemegang saham dan stakeholder, sehingga diharapkan dapat meningkatkan nilai perusahaan. Menurut Churet \& Eccles (2014) tidak terdapat hubungan yang signifikan antara integrated reporting dan kinerja keuangan perusahaan, yang diproksikan dengan Return on Investment Capital (ROIC). Kemudian Jeroe (2016) juga menunjukkan bahwa penerbitan integrated reporting berpengaruh negatif terhadap kinerja keuangan yang diukur dengan Earning per Share (EPS). Suttipun (2017) menunjukkan pelaporan manufactured capital berpengaruh positif terhadap kinerja keuangan perusahaan, sedangkan untuk pelaporan environmental capital berpengaruh negatif terhadap kinerja keuangan perusahaan yang diukur dengan Tobin's $Q$. Selanjutnya Cortesi \& Venay (2019) menunjukkan bahwa integrated reporting meningkatkan kualitas laba per saham yang dilaporkan.

$\mathrm{H}_{6}$ : Semakin tinggi luas pengungkapan IR, semakin tinggi nilai perusahaan.

Penelitian ini menggunakan dua variabel kontrol untuk menguji hubungan antara CG dan luas pengungkapan IR, yaitu jenis industri dan ukuran perusahaan. Variabel kontrol pertama, jenis industri mengasumsikan bahwa perusahaan yang beroperasi dalam industri yang sama aka mengadopsi pola informasi yang sama yang akan diberikan kepada stakeholder Watts \& Zimmerman, 1978 dalam (Indrawati et al., 2017). Variabel kontrol kedua, ukuran perusahaan mengasumsikan bahwa perusahaan yang besar akan melaporkan informasi lebih banyak daripada perusahaan kecil, baik informasi keuangan maupun nonkeuangan (Suttipun, 2017).

Secara sistematis, rerangka konseptual penelitian dapat dilihat pada Gambar 1 sebagai berikut: 


\section{Corporate Governance:}

1. Proporsi Komisaris Independen (Proportion of Independent Commissioners)

2. Keahlian Komite Audit (Audit Committee Expertise)

3. Frekuensi Pertemuan Komite Audit (Frequency of Audit Committee Meetings)

4. Kepemilikan Institusional (Institusional Ownership)

5. Kepemilikan Asing (Foreign Ownership)

Variabel Kontrol:

1. Jenis Industri (Industry Type)

2. Ukuran Perusahaan (Firm Size)

\section{Gambar 1. Rerangka Konseptual Penelitian}

Sumber: Data Penelitian, 2019

\section{METODE PENELITIAN}

Jenis penelitian yang dilakukan pada penelitian ini adalah penelitian penjelasan (explanatory research) dengan pendekatan kuantitatif. Penelitian ini dilakukan pada seluruh perusahaan publik yang terdaftar di Bursa Efek Indonesia (BEI) periode tahun 2017-2018.

Populasi penelitian adalah seluruh perusahaan publik yang terdaftar di Bursa Efek Indonesia (BEI) periode 2017-2018. Sampel penelitian ini dipilih dengan teknik purposive sampling.

Tabel 1. Perhitungan Sampel

\begin{tabular}{lll}
\hline No & Kriteria Pemilihan Sampel & Jumlah \\
\hline 1 & Perusahaan publik yang listing di BEI tahun 2017-2018 & 623 \\
2 & Perusahaan publik yang delisting tahun 2017-2018 & $(4)$ \\
3 & Perusahaan publik sektor keuangan tahun 2017-2018 karena sektor & \\
& keuangan memiliki karakteristik keuangan yang berbeda. & $(99)$ \\
4 & Perusahaan yang mengunakan mata uang asing & $(82)$ \\
5 & Perusahaan tidak menyajikan data lengkap 2017-2018 & $(277)$ \\
& Perusahaan yang memenuhi kriteria sampel & 161 \\
& Jumlah sampel (161 x 2 tahun) & 322 \\
\hline
\end{tabular}

Sumber: Data Penelitian, 2019 
Variabel dependen adalah luas pemgungkapan IR dan nilai perusahaan. Luas pengungkapan IR dalam AR perusahaan publik yang terdaftar dalam sampel diukur dengan Integrated Reporting Index (IRI) (Lipunga, 2015). IRI diukur dengan memberikan skor 1 untuk setiap indikator IR yang telah diterapkan oleh perusahaan dan skor 0 apabila elemen IR tidak diterapkan oleh perusahaan. Nilai perusahaan diukur dengan Tobin's $Q$.

Variabel independen dalam penelitian ini adalah CG, yang diproksikan dengan proporsi komisaris independen, keahlian komite audit, frekuensi pertemuan komite audit, kepemilikan institusional, dan kepemilikan asing. Proporsi komisaris independen diukur dengan jumlah komisaris independen dibagi total dewan komisaris. Keahlian komite audit diukur dengan jumlah anggota ahli keuangan dibagi total anggota. Frekuensi pertemuan komite audit diukur dengan jumlah total pertemuan yang dilakukan oleh komite audit dalam tahun berjalan. Kepemilikan institusional diukur dengan saham institusi dibagi total saham. Kepemilikan asing diukur dengan saham asing dibagi total saham.

Variabel kontrol adalah jenis industri dan ukuran perusahaan. Jenis industri diukur dengan menggunakan variabel dummy, 1 jika perusahaan high profile, dan 0 jika perusahaan low profile. Ukuran perusahaan diukur dengan logaritma natural dari total aset.

Model analisis yang digunakan dalam penelitian ini adalah model analisis regresi data panel. Uji regresi data panel digunakan untuk mengetahui pengaruh corporate governance terhadap luas pengungkapan integrated reporting.

Model regresi data panel dalam penelitian ini adalah sebagai berikut:

$\mathrm{IR}_{\mathrm{it}}=\alpha+\beta_{1} \mathrm{PIC}_{\mathrm{it}}+\beta_{2} \mathrm{ACE}_{\mathrm{it}}+\beta_{3} \mathrm{ACM}_{\mathrm{it}}+\beta_{4} \mathrm{IO}_{\mathrm{it}}+\beta_{5} \mathrm{FO}_{\mathrm{it}}+\beta_{6} \mathrm{Type}_{\mathrm{it}}+\beta_{7} \mathrm{Size}_{\mathrm{it}}+\varepsilon$.

$\mathrm{Q}_{\mathrm{it}}=\alpha+\beta_{1} I R_{\mathrm{it}}++\varepsilon$

Keterangan:

IR

: Luas pengungkapan integrated reporting

PIC : Proporsi komisaris independen

ACE : Keahlian komite audit

ACM : Frekuensi pertemuan komite audit

IO : Kepemilikan institusional

FO : Kepemilikan asing

Type : Jenis industri

Size : Ukuran perusahaan

Q : Nilai perusahaan

$\alpha \quad$ : Konstanta

$\beta_{1}-\beta_{7} \quad:$ Koefisien regresi

$\varepsilon \quad:$ Error

i : Perusahaan

t $\quad:$ Waktu

\section{HASIL DAN PEMBAHASAN}

Uji Chow, Hausman, dan Lagrange Multiplier (LM) digunakan untuk memilih model manakah yang paling tepat untuk digunakan dalam analisis regresi data panel. Berdasarkan hasil uji Chow, uji Hausman, dan uji LM pada model 1 dan 2 
pada penelitian ini menunjukkan bahwa model yang tepat digunakan adalah Random Effect Model.

Dalam penelitian ini tidak dilakukan uji normalitas karena jumlah observasi lebih dari 30 sehingga tidak perlu melakukan uji normalitas (Ajija et al., 2011:42). Uji asumsi klasik yang digunakan dalam penelitian ini adalah uji multikolinearitas, heteroskedastisitas, dan uji autokorelasi. Dari hasil uji asumsi klasik, seluruh data penelitian sudah bebas dari masalah multikolinearitas, heteroskedastisitas, dan autokorelasi.

\section{Tabel 2. Hasil Analisis Regresi Data Panel}

\begin{tabular}{lllll}
\hline Variable & Coefficient & Std. Error & t-Statistic & Prob. \\
\hline & & Model 1 & & \\
C & 0,236 & 0,089 & 2,659 & 0,008 \\
PIC & $-0,004$ & 0,024 & $-0,187$ & 0,851 \\
ACE & $-0,000$ & 0,015 & $-0,013$ & 0,990 \\
ACM & 0,001 & 0,000 & 2,247 & 0,025 \\
IO & $-0,000$ & 0,000 & $-0,581$ & 0,561 \\
FO & 0,000 & 0,000 & 0,508 & 0,612 \\
Type & 0,004 & 0,011 & 0,383 & 0,702 \\
Size & 0,014 & 0,003 & 4,822 & 0,000 \\
& & Model 2 & & \\
C & 0,051 & 2,721 & 0,019 & 0,985 \\
IR & 2,631 & 3,964 & 0,664 & 0,507 \\
& Model 1 & Model 2 & & \\
R-squared & 0,122 & 0,001 & & \\
Adjusted R-squared & 0,102 & $-0,002$ & & \\
F-statistic & 6,212 & 0,439 & & \\
Prob(F-statistic) & 0,000 & 0,508 & & \\
\hline
\end{tabular}

Sumber: Data Penelitian, 2019

Nilai Adjusted $R^{2}$ pada Model 1 yaitu sebesar 0,102 atau sebesar 10,2\%. Hal ini berarti keragaman luas pengungkapan IR dapat dijelaskan oleh variabel CG sebesar 10,2\%, sisanya sebesar 89,794\% dijelaskan oleh variabel selain dalam penelitian ini. Sementara itu, nilai Adjusted $R^{2}$ pada Model 2 yaitu sebesar -0,002 atau sebesar $-0,2 \%$. Hal ini berarti keragaman nilai perusahaan tidak dapat dijelaskan oleh variabel luas pengungkapan IR.

Nilai Prob(F-statistic) pada Model 1 sebesar 0,000 lebih kecil dari tingkat signifikansi 0,05 sehingga dapat disimpulkan bahwa model regresi yang diestimasi layak digunakan untuk menjelaskan pengaruh CG terhadap luas pengungkapan IR. Sementara itu, nilai Prob(F-statistic) pada Model 2 sebesar 0,508 lebih besar dari tingkat signifikansi 0,05 sehingga dapat disimpulkan bahwa model regresi yang diestimasi tidak layak digunakan untuk menjelaskan pengaruh luas pengungkapan IR terhadap nilai perusahaan. Dengan kata lain, model 2 sangat lemah untuk diuji.

Hipotesis pertama $\left(\mathrm{H}_{1}\right)$ menyatakan bahwa semakin tinggi proporsi komisaris independen, semakin tinggi luas pengungkapan IR. Hasil pengujian signifikansi koefisien regresi variabel proporsi komisaris independen menunjukkan nilai prob sebesar 0,8514 lebih besar dari a $=5 \%$. Hasil pengujian $\mathrm{H}_{1}$ menunjukkan bahwa semakin tinggi proporsi komisaris independen tidak akan meningkatkan luas pengungkapan IR, begitu pula sebaliknya. Oleh karena itu, 
$\mathrm{H}_{1}$ dalam penelitian ini ditolak. Hasil penelitian ini konsisten dengan penelitian Rouf (2011) yang membuktikan proprosi komisaris independen tidak berpengaruh terhadap pengungkapan sukarela. Ahmad (2017) juga membuktikan bahwa proporsi komisaris independen tidak berdampak terhadap luas pengungkapan IR. Namun, Frias-Aceituno et al. (2013) menyatakan sebaliknya, bahwa dewan direksi berhubungan dengan penyebaran integrated information. Proporsi komisaris independen tidak berpengaruh terhadap luas pengungkapan IR dapat membuktikan bahwa komisaris independen yang profesional sering kali memiliki ketakutan terhadap konsekuensi negatif dari pengungkapan informasi lebih banyak dari seharusnya, yaitu hilangnya reputasi ataupun kerugian kompetitif (Garcia-Sanchez et al., 2014 dalam Zaman et al., 2018). Selain itu, komisaris independen lebih memastikan melakukan pengungkapan wajib dan tidak tertarik untuk mengungkapkan di luar pengungkapan wajib (Zaman et al., 2018). Selain itu, walaupun tingkat proporsi komisaris independen tinggi, namun tingkat independensi dan keprofesionalan mereka tidak cukup baik, maka kinerja komisaris independen tentu saja akan menjadi tidak efektif (Ponnu, 2008). Keberadaan komisaris independen juga hanya untuk menjalankan ketetapak POJK No. 33/POJK.04/2014 bahwa perusahaan mimimal memiliki jumlah komisaris independen paling sedikit sebanyak 30\% dari jumlah seluruh anggota dewan komisaris. Tidak hanya itu, keberadaan komisaris independen di Indonesia tidak bisa dikatakan sebagai pihak yang netral.

Hipotesis kedua $\left(\mathrm{H}_{2}\right)$ menyatakan bahwa semakin tinggi keahlian komite audit, semakin tinggi luas pengungkapan IR. Hasil pengujian signifikansi koefisien regresi variabel keahlian komite audit menunjukkan nilai prob sebesar 0,9897 lebih besar dari $\alpha=5 \%$. Hasil pengujian $\mathrm{H}_{2}$ menunjukkan semakin tinggi keahlian komite audit tidak akan meningkatkan luas pengungkapkan IR, begitu pula sebaliknya. Oleh karena itu, $\mathrm{H}_{2}$ dalam penelitian ini ditolak. Hasil temuan ini sejalan dengan penelitian Haji \& Anifowose (2016) yang menyatakan bahwa keahlian komite audit tidak berpengaruh terhadap praktik IR. Kontradiksi dengan hasil temuan Haji \& Anifowose (2016), Haji (2015) menunjukkan terdapat hubungan positif signifikan antara keahlian komite audit dengan voluntary disclosure, yaitu pengungkapan intellectual capital. Selain itu, Chariri \& Januarti (2017) juga menyatakan bahwa keahlian komite audit berpengaruh positif terhadap luas lingkup IR. Hasil ini membuktikan bahwa keahlian komite audit sepertinya kurang memberikan pengaruh yang besar terhadap luas pengungkapan IR. Tidak adanya pengaruh keahlian komite audit menunjukkan bahwa selain keahlian keuangan dan/atau akuntansi, komite audit juga harus memiliki keahlian lain, seperti keahlian dalam tata kelola dan keahlian industri dalam menghasilkan kualitas pelaporan perusahaan (Bédard et al., 2004 dalam Haji \& Anifowose, 2016). Selain itu, komite audit juga harus di dorong untuk memiliki keahlian yang relevan, termasuk dalam bidang industri, teknologi, hukum, kepemimpinan, dan tata kelola (Baatwah et al., 2013).

Hipotesis ketiga $\left(\mathrm{H}_{3}\right)$ menyatakan bahwa semakin tinggi frekuensi pertemuan komite audit, semakin tinggi luas pengungkapan IR. Hasil pengujian signifikansi koefisien regresi variabel frekuensi pertemuan komite audit menunjukkan nilai prob sebesar 0,0254 lebih kecil dari $a=5 \%$. Hasil pengujian $\mathrm{H}_{3}$ 
menunjukkan semakin tinggi frekuensi pertemuan komite audit, semakin tinggi luas pengungkapkan IR, begitu pula sebaliknya. Oleh karena itu, $\mathrm{H}_{3}$ dalam penelitian ini diterima. Selanjutnya, nilai koefisien frekuensi pertemuan komite audit adalah 0,001501. Hal ini menunjukkan bahwa arah hubungan antara frekuensi pertemuan komite audit dan luas pengungkapan IR positif, sesuai dengan yang diprediksikan pada hipotesis ketiga. Oleh karena itu, dapat disimpulkan bahwa perusahaan yang lebih sering melakukan pertemuan komite audit memiliki tingkat pengungkapan IR yang tinggi. Hasil penelitian ini konsisten dengan penelitian Haji (2015) yang menemukan bahwa komite audit yang melakukan pertemuan rutin berpengaruh positif signifikan terhadap voluntary disclosure, yaitu pengungkapan intellectual capital. Haji \& Anifowose (2016) dan Chariri \& Januarti (2017) juga menemukan bahwa semakin sering komite audit melakukan pertemuan rutin, maka semakin tinggi luas pengungkapan IR. Pertemuan komite audit selama periode 2017 dan 2018 ratarata sebanyak 7 kali per tahun. Berdasarkan ketentuan POJK No. 55/POJK.04/2015, komite audit melakukan pertemuan paling sedikit satu kali dalam tiga bulan atau empat kali dalam setahun. Hal ini menunjukkan bahwa pertemuan komite audit sudah sesuai bahkan melebihi peraturan yang telah ditetapkan sehingga berdampak terhadap luas pengungkapan IR. Adanya hubungan positif signifikan antara frekuensi pertemuan komite audit dengan luas pengungkapan IR membuktikan bahwa komite audit telah melakukan fungsi pengawasan yang efektif dan efisien. Dengan melakukan pertemuan rutin, memungkinkan komite audit untuk membahas masalah yang berkaitan dengan perusahaan, termasuk membahas mengenai IR (Chariri \& Januarti, 2017). Haji (2015) juga menemukan bahwa komite audit yang melakukan pertemuan rutin dapat meningkatkan kualitas pelaporan perusahaan.

Hipotesis keempat $\left(\mathrm{H}_{4}\right)$ menyatakan bahwa semakin tinggi kepemilikan institusional, semakin tinggi luas pengungkapan IR. Hasil pengujian signifikansi koefisien regresi variabel kepemilikan institusional menunjukkan nilai prob sebesar 0,5613 lebih besar dari $a=5 \%$. Hasil pengujian $\mathrm{H}_{4}$ menunjukkan semakin tinggi kepemilikan institusional tidak akan meningkatkan luas pengungkapkan IR, begitu pula sebaliknya. Oleh karena itu, $\mathrm{H}_{4}$ dalam penelitian ini ditolak. Hasil penelitian ini konsisten dengan penelitian Ahmad (2017), Indrawati et al. (2017), dan Novaridha (2017) yang menunjukkan bahwa kepemilikan institusional tidak berpengaruh terhadap IR. Tidak berpengaruhnya kepemilikan institusional terhadap luas pengungkapan IR dapat diakibatkan karena pihak institusi di Indonesia belum memperhitungkan elemen IR dalam annual report sebagai salah satu pertimbangan dalam pengambulan keputusan investasi. Selain itu, pihak institusi mementingkan terhadap peningkatan laba dan kinerja perusahaan dibandingkan pengungkapan informasi nonkeuangan yang lebih luas, termasuk pengungkapan elemen IR.

Hipotesis kelima $\left(\mathrm{H}_{5}\right)$ menyatakan bahwa semakin tinggi kepemilikan asing, semakin tinggi luas pengungkapan IR. Hasil pengujian signifikansi koefisien regresi variabel kepemilikan asing menunjukkan nilai prob sebesar 0,6116 lebih besar dari $\alpha=5 \%$. Hasil pengujian $\mathrm{H}_{5}$ menunjukkan semakin tinggi kepemilikan asing tidak akan meningkatkan luas pengungkapkan IR, begitu pula sebaliknya. Oleh karena itu, $\mathrm{H}_{5}$ dalam penelitian ini ditolak. Hasil penelitian ini 
konsisten dengan penelitian Ahmad (2017) yang menunjukkan bahwa kepemilikan asing tidak berpengaruh terhadap IR. Terdapat beberapa hal yang menyebabkan kepemilikan asing tidak berpengaruh terhadap luas pengungkapan IR, yaitu investor asing pada perusahaan publik yang listing di Indonesia belum memfokuskan perusahaan untuk mengungkapkan informasi yang lebih luas, termasuk pengungkapan IR. Selain itu, rata-rata persentasi kepemilikan asing pada perusahaan publik di Indonesia masih rendah, sehingga pengawasan oleh investor asing masih lemah.

Hipotesis keenam $\left(\mathrm{H}_{6}\right)$ menyatakan bahwa semakin tinggi luas pengungkapan IR, semakin tinggi nilai perusahaan. Hasil pengujian signifikansi koefisien regresi variabel luas pengungkapan IR menunjukkan nilai prob sebesar 0,5073 lebih besar dari $\mathrm{a}=5 \%$. Hasil pengujian $\mathrm{H}_{6}$ menunjukkan semakin tinggi luas pengungkapan IR tidak akan meningkatkan nilai perusahaan, begitu pula sebaliknya. Oleh karena itu, $\mathrm{H}_{6}$ dalam penelitian ini ditolak. Hasil penelitian ini konsisten dengan penelitian Churet \& Eccles (2014) yang menemukan bahwa IR tidak berpengaruh terhadap kinerja keuangan perusahaan. Kemudian Jeroe (2016) dan Suttipun (2017) menunjukkan bahwa integrated annual report berpengaruh negatif terhadap kinerja keuangan perusahaan. Hasil ini membuktikan bahwa value creation yang merupakan esensi dari IR tidak harus diungkapkan dalam integrated reporting saja, tetapi juga pada laporan tahunan dan laporan keberlanjutan (Dosinta et al., 2018). Selain itu, belum ada perusahaan publik di Indonesia yang melakukan pengungkapan IR. Para investor di Indonesia juga belum terlalu mementingkan perlunya keberlanjutan jangka panjang, sehingga perusahaan publik di Indonesia belum ada yang melalukan pengungkapan IR.

\section{SIMPULAN}

Penelitian ini bertujuan untuk menganalisis pengaruh corporate governance terhadap luas pengungkapan integrated reporting dan implikasinya terhadap nilai perusahaan pada perusahaan publik yang terdaftar di Bursa Efek Indonesia periode 2017-2018 dengan menggunakan analisis regresi data panel.

Corporate governance dalam penelitian ini diproksikan dengan proporsi komisaris independen, keahlian komite audit, frekuensi pertemuan komite audit, kepemilikan institusional, dan kepemilikan asing.

Hasil penelitian ini menemukan bahwa frekuensi pertemuan komite audit berpengaruh positif signifikan terhadap luas pengungkapan integrated reporting. Hasil ini mengindikasikan bahwa semakin tinggi frekuensi pertemuan komite audit akan meningkatkan luas pengungkapan integrated reporting perusahaan, demikian pula sebaliknya. Dengan demikian, hubungan positif signifikan antara frekuensi komite audit dengan luas pengungkapan integrated reporting menunjukkan bahwa rapat yang dilakukan oleh komite audit merupakan kegiatan pengawasan yang efektif.

Sementara itu, proporsi komisaris independen, keahlian komite audit, kepemilikan institusional, dan kepemilikan asing tidak berpengaruh signifikan terhadap luas pengungkapan integrated reporting. Hal ini menunjukkan bahwa besar kecilnya proprosi komisaris independen, keahlian komite audit, 
kepemilikan institusional, dan kepemilikan asing tidak akan meningkatkan luas pengungkapan integrated reporting perusahaan.

Keterbatasan pada penelitian ini diharapkan dapat memberikan arah bagi penelitian mendatang. Pertama, penelitian ini menggunakan data pada annual report untuk content analysis pengungkapan integrated reporting. Informasi yang diberikan pada annual report belum menggambarkan keadaan sebenarnya dari IR karena menggunakan annual report bukannya integrated reporting, sehingga hasil perhitungan pengungkapan integrated reporting dalam penelitian ini masih terbatas. Item pengungkapan integrated reporting dalam penelitian ini mengacu pada instrumen penelitian Lipunga (2015) yang tidak menunjukkan kondisi di Indonesia. Oleh karena itu, diperlukan analisis lebih dalam mengenai pengungkapan integrated reporting dengan menyelaraskan keadaan di Indonesia. Kedua, penelitian ini menggunakan variabel corporate governance yang diproksikan dengan proporsi komisaris independen, keahlian dan frekuensi pertemuan komite audit, serta kepemilikan institusional dan kepemilikan asing hanya mampu menjelaskan variabel luas pengungkapan integrated reporting sebesar $10 \%$ dan sisanya dipengaruhi oleh variabel lain. Untuk penelitian mendatang, hendaknya menambahkan variabel lainnya seperti kinerja keuangan yaitu Return on Asset (ROA) ataupun Earning per Share (EPS). Kinerja keuangan diharapkan dapat berpengaruh terhadap luas pengungkapan integrated reporting. Saran selanjutnya, yaitu menambahkan variabel growth opportunities. Perusahaan yang memiliki nilai growth opportunities yang tinggi diharapkan dapat mengungkapkan volume informasi yang lebih besar untuk mengurangi adanya asimetri informasi.

\section{REFERENSI}

Abernathy, J. L., Herrmann, D., Kang, T., \& Krishnan, G. V. (2013). Audit Committee Financial Expertise and Properties of Analyst Earnings Forecasts. Advances in Accounting, Incorporating Advances in International Accounting, 29(1), 1-11. https://doi.org/10.1016/j.adiac.2012.12.001

Adams, S., \& Simnett, R. (2011). Integrated Reporting: An Opportunity for Australia's Not-for-Profit Sector. Australian Accounting Review, 21(3), 292-301. https://doi.org/10.1111/j.1835-2561.2011.00143.x

Ahmad, R. (2017). Pengaruh Struktur Corporate Governance terhadap Tingkat Keselarasan Laporan Tahunan dengan Rerangka Integrated Reproting (Universitas Negeri Yogyakarta). Retrieved from http://www.albayan.ae

Ajija, S. R., Sari, D. W., Setianto, R. H., \& Primanti, M. R. (2011). Cara Cerdas Menguasai EViews. Jakarta: Salemba Empat.

Akhtaruddin, M., \& Haron, H. (2010). Board Ownership, Audit Committees' Effectiveness, and Corporate Voluntary Disclosures. Asian Review of Accounting, 18(1), 68-82. https:/ / doi.org/10.1108/13217341011089649

Baatwah, S. R., Salleh, Z., \& Ahmad, N. (2013). Whether Audit Committee Financial Expertise Is the Only Relevant Expertise: A Review of Audit Committee Expertise and Timeliness of Financial Reporting. Issues in Social and Environmental Accounting, 7(2), 86-101. 
Busco, C., Frigo, M. L., Quattrone, P., \& Riccaboni, A. (2013). Redefining Corporate Accountability through Integrated Reporting. Strategic Finance, 33-41.

Chariri, A., \& Januarti, I. (2017). Eksplorasi Elemen Integrated Reporting dalam Annual Reports Perusahaan di Indonesia. Jurnal Akuntansi, 21(3), 411424. https:// doi.org/10.24912/ja.v21i3.245

Churet, C., \& Eccles, R. G. (2014). Integrated Reporting, Quality of Management, and Financial Performance. Journal of Applied Corporate Finance, 26(1), 8-16. https:// doi.org/10.1111/jacf.12054

Cohen, J. R., Holder-Webb, L. L., Nath, L., \& Wood, D. (2012). Corporate Reporting of Nonfinancial Leading Indicators of Economic Performance and Sustainability. Accounting Horizons, 26(1), 65-90. https:// doi.org/10.2308/acch-50073

Cortesi, A., \& Venay, L. (2019). Disclosure Quality under Integrated Reporting: A Value Relevance Approach. Journal of Cleaner Production, 220(20), 745755. https:/ / doi.org/10.1016/j.jclepro.2019.02.155

Dosinta, N. F., Brata, H., \& Heniwati, E. (2018). Haruskah Value Creation Hanya Terdapat Pada Integrated Reporting? Jurnal Akuntansi Multiparadigma, 9(2), 248-266. https:// doi.org/10.18202/jamal.2018.04.9015

Frias-Aceituno, J. V, Rodriguez-Ariza, L., \& Garcia-Sanchez, I. M. (2013). The Role of the Board in the Dissemination of Integrated Corporate Social Reporting. Corporate Social Responsibility and Environmental Management, 20(4), 219-233. https:/ / doi.org/10.1002/csr.1294

Haji, A. A. (2015). The Role of Audit Committee Attributes in Intellectual Capital Disclosures: Evidence from Malaysia. Managerial Auditing Journal, 30(8/9), 756-784.

Haji, A. A., \& Anifowose, M. (2016). Audit Committee and Integrated Reporting Practices: Does Internal Assurance Matter. Managerial Auditing Journal, 31(8/9). https:// doi.org/10.1108/MAJ-10-2016-1464

Hermalin, B. E., \& Weisbach, M. S. (1988). The Determinants of Board Composition. RAND Journal of Economics, 19(4), 589-606. https:// doi.org/10.2307/2555459

IIRC. (2013). The International IR Framework.

Indrawati, N., Darlis, E., \& Azhar, A. (2017). The Accuracy of Earning Forecast Analysis , Information Asymmetry and Integrated Reporting - Case of Indonesia. Jurnal Dinamika Akuntansi Dan Bisnis, 4(1), 19-32.

Indrawati, N., Darlis, E., \& L., A. A. (2017). The Accuracy of Earning Forecast Analysis, Information Asymmetry and Integrated Reporting-Case of Indonesia. Jurnal Dinamika Akuntansi Dan Bisnis, 4(1), 19-32. https:// doi.org/10.24815/jdab.v4i1.5843

Jeroe, A. S. (2016). Integrated Reporting, Non-Financial Information and Financial Performance. Erasmus University Rotterdam.

Lipunga, A. M. (2015). Integrated Reporting in Developing Countries: Evidence from Malawi. Journal of Management Research, 7(3), 130-156. https:// doi.org/10.5296/jmr.v7i3.7195

Lisic, L. L., Neal, T. L., Zhang, I. X., \& Zhang, Y. (2015). CEO Power , Internal Control Quality, and Audit Committee Effectiveness in Substance 
Versus in Form. Contemporary Accounting Research, 33(3), 1-39. https:// doi.org/10.1111/1911-3846.12177

Nindiasari, A. D. (2018). Atribut Corporate Governance dan Voluntary Disclosure. Universitas Islam Indonesia.

Novaridha, I. A. (2017). Pengaruh Kepemilikan Institusional, Ukuran Perusahaan dan Profitabilitas terhadap Elemen-Elemen Integrated Reporting. Jurnal Online Mahasiswa Fakultas Ekonomi, 4(1), 3399-3411.

Nurrahman, A., \& Sudarno. (2013). Pengaruh Kepemilikan Manajerial, Kepemilikan Institusional, dan Kepemlikan Asing terhadap Praktik Pengungkapan Sustainability Report. Diponegoro Journal of Accounting, 2(1), 1-13.

Ponnu, C. H. (2008). Corporate Governance Structures and the Performance of Malaysian Public Listed Companies. International Review of Business Research Papers, 4(2), 217-230.

PwC. (2012). Integrated Reporting: The Future of Corporate Reporting. https://doi.org/10.1057/978-1-137-52766-0_21

RMOL. (2012). Kasus Bakrie dan Sumalindo di Pasar Modal Akibat Ketiadaan Transparansi. Retrieved November 23, 2019, from https://ekbis.rmol.id/read/2012/12/17/90339/

Rouf, A. (2011). Corporate Characteristics, Governance Attributes and the Extent of Voluntary Disclosure in Bangladesh. African Journal of Business Management, 5(19), 7836-7845. https:/ / doi.org/10.5897/ AJBM10.1180

Serafeim, G. (2015). Integrated Reporting and Investor Clientele. Journal of Applied Corporate Finance, 27(2), 34-52. https://doi.org/10.1097/FCH.0000000000000187

Suttipun, M. (2017). The Effect of Integrated Reporting on Corporate Financial Performance: Evidence from Thailand. Corporate Ownership and Control, 15(1), 133-142. https:/ / doi.org/10.22495/cocv15i1art13

Tamba, E. G. H. (2011). Pengaruh Struktur Kepemilikan terhadap Pengungkapan Tanggung Jawab Sosial Perusahaan. Universitas Diponegoro Semarang.

Utami, K. (2016). Disclosure dan Cost of Capital: Implementasi Integrated Reporting di Asia Pasifik. Simposium Nasional Akuntansi, 19, 1-23.

Wulandari, N. P. Y., \& Budiartha, I. K. (2014). Pengaruh Struktur Kepemilikan, Komite Audit, Komisaris Independen Dan Dewan Direksi Terhadap Integritas Laporan Keuangan. E-Jurnal Akuntansi Universitas Udayana, 7(3), 574-586.

Wulandari, P. A., \& Kiswanto. (2016). Mekanisme Corporate Governance terhadap Kinerja Lingkungan dengan Profitabilitas sebagai Mediator. Accounting Analysis Journal, 5(1), 1-10.

Zaman, R., Bahadar, S., Kayani, U. N., \& Arslan, M. (2018). Role of Media and Independent Directors in Corporate Transparency and Disclosure: Evidence from an Emerging Economy. Corporate Governance: The International Journal of Business in Society. https://doi.org/10.1108/CG01-2018-0042 